\title{
Eyes Partial Response GvHD
}

National Cancer Institute

\section{Source}

National Cancer Institute. Eyes Partial Response GVHD. NCI Thesaurus. Code C126715.

An NIH eye score that has decreased by 1 or more points. 